\title{
Germline Missense Changes in the APC Gene and Their Relationship to Disease
}

\author{
Rodney J. Scott', ${ }^{1,2}$ Renee Crooks', Lindy Rose', John Attia ${ }^{3}$, Ammarin Thakkinstian', \\ Lesley Thomas', Allan D. Spigelman', Cliff J. Meldrum² \\ Discipline of Medical Genetics, Faculty of Health, University of Newcastle, and the Hunter Medical Research Institute, Australia; 2Division of Genetics, Hunter Area \\ Pathology Service, Australia; ${ }^{3}$ Centre for Clinical Epidemiology and Biostatistics, University of Newcastle, Australia; ${ }^{4}$ Clinical Epidemiology Unit, Faculty of Medicine, \\ Ramathibodi Hospital, Mahidol University, Bangkok, Thailand; ${ }^{5}$ Discipline of Surgical Science, Faculty of Health, University of Newcastle, and The Hunter Medical \\ Research Institute, Australia
}

Key words: $A P C$, mutations, colorectal cancer, missense

Corresponding author: Rodney J. Scott, Hunter Area Pathology Service, Locked Bag 1, Hunter Regional Mail Centre, Newcastle NSW 2310,Australia.E-mail: rodney.scott@newcastle.edu.au

Submitted: 30 April 2004

Accepted: 15 May 2004

\begin{abstract}
Familial adenomatous polyposis (FAP) is characterized by the presence of hundreds to thousands of adenomas that carpet the entire colon and rectum. Nonsense and frameshift mutations in the adenomatous polyposis coli (APC) gene account for the majority of mutations identified to date and predispose primarily to the typical disease phenotype. Some APC mutations are associated with a milder form of the disease known as attenuated FAP. Virtually all mutations that have been described in the APC gene result in the formation of a premature stop codon and very little is known about missense mutations apart from a common Ashkenazi Jewish mutation (1307K) and a British E1317Q missense change. The incidence of missense mutations in the APC gene has been underreported since the APC gene lends itself to analysis using an artificial transcription and translation assay known as the Protein Truncation Test (PTT) or the In Vitro Synthetic Protein assay (IVSP).

In this report we have used denaturing high performance liquid chromatography to analyse the entire coding sequence of the APC gene to determine if a cohort of patients adhering to the diagnostic criteria of FAP to assess the frequency of missense mutations in the APC gene. Altogether 112 patients were studied and 22 missense mutations were identified. From the total of 22 missense changes, 13 were silent changes and the remaining 9 resulted in amino acid substitutions. One or more of these changes were identified multiple times in $62.5 \%$ of the population under study.

The results reveal that missense mutations in the APC gene appear not to radically alter protein function but may be associated with more subtle processing of RNA transcripts which in turn could result in the expression of differentially spliced forms of the APC gene which may interfere with the functional activity of the APC protein.
\end{abstract}

\section{Introduction}

Familial adenomatous polyposis (FAP) is characterized by the development of hundreds to thousands of adenomas throughout the entire colon and rectum, which if not removed will almost certainly result in the development of colorectal cancer [1]. Variance in disease expression has also been described and is typified by fewer colonic and rectal adenomas (usually fewer than 100), later age of onset and a reduced likelihood of colorectal cancer development. Variant forms of FAP are known as attenuated 
adenomatous polyposis (AAPC) or the flat adenoma syndrome [2,3]. The population incidence of FAP is approximately 1:7000 according to the Danish Polyposis Registry and it affects both sexes equally.

The genetic basis of FAP was first localized to chromosome $5 q$ in 1986 and the region localized to $5 q 21$ in $1987[4,5]$. In 1991 a gene for FAP was identified and called the APC gene [6-9]. The APC gene is composed of 15 exons, the first 14 being relatively small whereas exon 15 is extremely large (6500 bp), representing approximately $75 \%$ of the coding sequence.

The APC protein is multifunctional and its primary role appears to be linked to the breakdown of $\beta$-catenin via the ubiquitin degradation pathway [10]. Several other proteins not associated with that pathway have been shown to bind to the APC protein suggesting a diversity of function [1 1, 12]. The majority of mutations occur within a section of the gene known as the mutation cluster region bounded by codons 1286 and 1513 [13].

Since the APC consists of a large contiguous coding sequence of DNA (exon 15) it lends itself to analysis by the protein truncation test (PTT). The PTT is unique in that it is an assay, which specifically detects premature termination signals using an artificial transcription translation assay but is not capable of identifying missense changes, which may have an affect of protein function and consequently disease risk [14]. Most groups studying the APC gene tend to use the PTT and have not necessarily submitted samples for more intensive interrogation. Added to this there are few reports detailing missense changes in the APC gene except for two polymorphisms, I1307K and E1317Q, both of which have been associated with an increased risk of developing multiple adenomas and colorectal cancer, for review see Fearnhead et al 2001 [15]. Additional missense changes have been reported in one series of FAP patients that identified several different polymorphisms, the majority of which were silent changes [16]. Few other reports have been published that describe missense changes in the APC gene [13, 17] and their relationship to disease expression. The paucity of missense mutations identified in the APC gene is in contrast to such changes identified in BRCA1, BRCA2 and genes involved in DNA mismatch repair. Several missense mutations identified in BRCA1, BRCA2 and the DNA mismatch repair genes are clearly associated with disease risk as they unequivocally result in a perturbation of protein function [18, 19]. In contrast, all missense changes that have been identified in the APC gene have not been categorically linked with a change in protein function. It is only by association that missense changes have been implicated in the risk of developing FAP [20].

In this report we have screened the entire coding region of the APC gene by DHPLC analysis in a large series of patients to determine the frequency of missense changes in the APC gene and to assess their role in the development of florid polyposis. From a series of 112 patients a total of 22 different missense changes were identified of which 13 were silent polymorphisms and 9 resulted in an amino acid change.

\section{Materials and methods}

\section{Patients}

A group of 112 unrelated patients of British and European descent fulfilling the diagnostic criteria for FAP were included in the study for mutations in the APC gene. Probands were identified at family cancer clinics that cover the entire state of New South Wales, including the Australian Capitol Territory. All probands gave informed consent for genetic testing. In addition to the FAP patients used for this study a series of unidentifiable control samples of DNA taken from a population at random were also included in the analysis. Of the 112 patients, 12 presented with colonic and extra-colonic disease, 4 were described as having attenuated disease and there were 14 patients who did not have a family history of disease but did present with florid polyposis. The remaining 82 patients only presented with colonic polyposis but did have strong family histories of colorectal cancer consistent with an autosomal dominant inheritance pattern. For statistical purposes patients were classified into three categories: mild, moderate and severe disease. Mild disease represented patients over the age of 60 with multiple polyps (over 20), moderate disease represented patients with polyposis (over 100) and cancer over the age of 60 and severe disease was considered to cover typical symptoms of polyposis (100s to 1000s of adenomas) under the age of 50 with or without cancer.

\section{DNA isolation}

Genomic DNA was isolated from $\mathrm{Na}_{2}$ EDTA blood according to the method described by Miller et al 1988 [21].

\section{D-HPLC analysis}

PCR amplification for DHPLC analysis was performed using primers that were identical to those 
described for DGGE (except that the GC-clamp was not included) analysis of exons $1-14$ of the APC gene [22] and primers designed specifically for exon 15 (see Table 1). The reaction consisted of $1.0 \mu \mathrm{M}$ each primer, $1 U$ Platinum Taq (Gibco-BRL), 2 - 5 mM $\mathrm{MgCl}_{2}$ and $200 \mu \mathrm{M}$ each dNTP. PCR amplification was achieved by an initial denaturation at $94^{\circ} \mathrm{C}$ for $5 \mathrm{~min}$ followed by 14 cycles of $94^{\circ} \mathrm{C}$ for $1 \mathrm{~min}, 7^{\circ} \mathrm{C}$ touchdown range for $1.5 \mathrm{~min}$ and $72^{\circ} \mathrm{C}$ for $2 \mathrm{~min}$, then 20 cycles using an annealing temperature $0.5^{\circ} \mathrm{C}$ lower than the bottom of the touchdown range. The initial annealing step was performed as a touchdown protocol with a $7^{\circ} \mathrm{C}$ range, decreasing $0.5^{\circ} \mathrm{C} / \mathrm{cycle}$ over 14 cycles. This was followed by a final extension step at $72^{\circ} \mathrm{C}$ for $10 \mathrm{~min}$, a final denaturation step at $95^{\circ} \mathrm{C}$ for 5 min and a slow annealing step from $95^{\circ} \mathrm{C}$ to $65^{\circ} \mathrm{C}$ over $30 \mathrm{~min}$ to promote heteroduplex formation. The PCR was performed on a PCR express (Hybaid) instrument equipped with a heated lid to avoid the use of mineral oil.

DHPLC analysis was performed using a Varian Helix system (Varian, Inc., Walnut Creek, CA). PCR products $(2-5 \mu \mathrm{l})$ were injected directly into a DNA Eclipse (Hewlett Packard) or Helix (Varian) column and eluted from the column using an increasing acetonitrile gradient and a column oven temperature suitable for each exon and fragment of the APC gene (see Table 1). Heteroduplexes formed during PCR of a heterozygote sample were detected as an additional peak eluting before the homoduplex peak. The detection of heteroduplexes was made simpler with the use of DHPLC review software supplied as a prototype from Varian. The predicted melting temperatures of the double stranded DNA products were obtained by using the DHPLC-MELT program available from http://www.insertion.stanford.edu/melt.ht.

\section{DNA sequencing}

All polymorphisms were subject to DNA sequencing to determine the precise genetic change on a semiautomated sequencing unit (model 310, Perkin-Elmer Applied Biosystems Division, Foster City, CA).

\section{Statistics}

Linkage disequilibrium was assessed by estimating a correlation coefficient (program kindly provided by D. Clayton, personal communication) and using a likelihood ratio test. Haplotype frequency was inferred using the E-M algorithm [23]. All statistics were performed using STATA version 8.0 software [24].
Table 1. Primers used for the analysis of exon 15 of the APC gene

\begin{tabular}{|c|c|c|}
\hline Segment & Sequence & $\begin{array}{c}\text { Oven } \\
\text { Temperature }\left({ }^{\circ} \mathrm{C}\right)\end{array}$ \\
\hline $\begin{array}{l}\text { FAPex15.1 For } \\
\text { FAPex15.1Rev }\end{array}$ & $\begin{array}{l}\text { gttactgcatacacattgtgac } \\
\text { gctllttghtttcctaacatgaag }\end{array}$ & 50,59 \\
\hline $\begin{array}{l}\text { FAPex15.2For } \\
\text { FAPex15.2Rev }\end{array}$ & $\begin{array}{l}\text { agtacaaggatgccaatattatg } \\
\text { acttctatcttlltcagaacgag }\end{array}$ & 50,59 \\
\hline $\begin{array}{l}\text { FAPex15.3For } \\
\text { FAPex15.3Rev }\end{array}$ & $\begin{array}{l}\text { attlgaatactacagtgittaccc } \\
\text { cttgtattctaattlggcataagg }\end{array}$ & $50,54,60$ \\
\hline $\begin{array}{l}\text { FAPex15.4For } \\
\text { FAPex15.4Rev }\end{array}$ & $\begin{array}{l}\text { ctgcccatacacaltcaaacac } \\
\text { tgittgggtcttgcccatctt }\end{array}$ & $50,55,57$ \\
\hline $\begin{array}{l}\text { FAPex 15.5For } \\
\text { FAPex 15.5Rev }\end{array}$ & $\begin{array}{l}\text { agtcttaaatattcagatgagcag } \\
\text { gittctcttcattatattltatgcta }\end{array}$ & 50,52 \\
\hline $\begin{array}{l}\text { FAPex 15.6For } \\
\text { FAPex15.6Rev }\end{array}$ & $\begin{array}{l}\text { aagcctaccaattatagtgaacg } \\
\text { agctgatgacaaagatgataatg }\end{array}$ & 50,59 \\
\hline $\begin{array}{l}\text { FAPex 15.7For } \\
\text { FAPex15.7Rev }\end{array}$ & $\begin{array}{l}\text { aagaaacaatacagactlattgtg } \\
\text { atgagtggggtctcctgaac }\end{array}$ & $50,54,59$ \\
\hline $\begin{array}{l}\text { FAPex 15.8For } \\
\text { FAPex15.8Rev }\end{array}$ & $\begin{array}{l}\text { atctccctccaaaagtggtgc } \\
\text { tccatctggagtacttlccgtg }\end{array}$ & 50,60 \\
\hline $\begin{array}{l}\text { FAPex 15.9aFor } \\
\text { FAPex15.9aRev }\end{array}$ & $\begin{array}{l}\text { agtaaatgctgcagttcagagg } \\
\text { catcatcatctgaatcatcta }\end{array}$ & 50,58 \\
\hline $\begin{array}{l}\text { FAPex15.9bFor } \\
\text { FAPex15.9bRev }\end{array}$ & $\begin{array}{l}\text { accaagagaaagaggcag } \\
\text { ccgtgg catatcatccccc }\end{array}$ & $50,54,59$ \\
\hline $\begin{array}{l}\text { FAPex15.10For } \\
\text { FAPex15.10Rev }\end{array}$ & $\begin{array}{l}\text { gcccagactgcttcaaaattacc } \\
\text { gagcctcatctgtacttctge }\end{array}$ & 50,61 \\
\hline $\begin{array}{l}\text { FAPex 15.11 For } \\
\text { FAPex15.11Rev }\end{array}$ & $\begin{array}{l}\text { ccctccaaatgagttagctgc } \\
\text { Htgtggtatagg thltactggtg }\end{array}$ & $50,54,60$ \\
\hline $\begin{array}{l}\text { FAPex 15.12For } \\
\text { FAPex15.12Rev }\end{array}$ & $\begin{array}{l}\text { acccaacaaaaatcagttagatg } \\
\text { gtggctggtaacttlagcctc }\end{array}$ & 50,57 \\
\hline $\begin{array}{l}\text { FAPex 15.13For } \\
\text { FAPex 15.13Rev }\end{array}$ & $\begin{array}{l}\text { atgatg ttgacctttccaggg } \\
\text { gctcagtctctttgataggttc }\end{array}$ & 50,58 \\
\hline $\begin{array}{l}\text { FAPex15.14For } \\
\text { FAPex15.14Rev }\end{array}$ & $\begin{array}{l}\text { ctgagttctctcagtgacattgac } \\
\text { gttctgaatctggtctctg }\end{array}$ & 50,58 \\
\hline $\begin{array}{l}\text { FAPex 15.15For } \\
\text { FAPex15.15Rev }\end{array}$ & $\begin{array}{l}\text { tatgggtggcatattaggtg } \\
\text { ccttlactltcagattctatc }\end{array}$ & 50,59 \\
\hline $\begin{array}{l}\text { FAPex 15.16For } \\
\text { FAPex15.16Rev }\end{array}$ & $\begin{array}{l}\text { aggeccacgaattctaaaacc } \\
\text { cctggcaacaggg cttaattc }\end{array}$ & $50,54,58$ \\
\hline $\begin{array}{l}\text { FAPex 15.17For } \\
\text { FAPex15.17Rev }\end{array}$ & $\begin{array}{l}\text { gaaggtcaaacagccacc } \\
\text { ggcattcttggataaacctg }\end{array}$ & 50,59 \\
\hline $\begin{array}{l}\text { FAPex 15.18For } \\
\text { FAPex15.18Rev }\end{array}$ & $\begin{array}{l}\text { catctccaggtagacagatgag } \\
\text { cttaaaactggagtttgtgectg }\end{array}$ & 50,59 \\
\hline $\begin{array}{l}\text { FAPex15.19For } \\
\text { FAPex15.19Rev }\end{array}$ & $\begin{array}{l}\text { ctccatcatctagaccagc } \\
\text { cactggattctgatgaage }\end{array}$ & 50,61 \\
\hline $\begin{array}{l}\text { FAPex 15.20For } \\
\text { FAPex15.20Rev }\end{array}$ & $\begin{array}{l}\text { tggagaagaactggaagttc } \\
\text { gggagatcttccagatctagg }\end{array}$ & 50,58 \\
\hline $\begin{array}{l}\text { FAPex 15.21 For } \\
\text { FAPex15.21Rev }\end{array}$ & $\begin{array}{l}\text { acagaggatgittgggtgag } \\
\text { gcttgagctgctagaactg }\end{array}$ & 50,60 \\
\hline $\begin{array}{l}\text { FAPex 15.22For } \\
\text { FAPex 15.22Rev }\end{array}$ & $\begin{array}{l}\text { cctgtatcagagactaatg } \\
\text { caaaatgtctatatagcagttg }\end{array}$ & $50,55,60$ \\
\hline
\end{tabular}


Table 2. Silent polymorphisms in the APC gene

\begin{tabular}{lllll}
\hline Exon & Nucleotide change & Codon & Number of times observed & New \\
\hline 12 & $1554 \mathrm{G}>\mathrm{A}^{*}$ & 518 & 1 & Yes \\
\hline 13 & $1635 \mathrm{~A}>\mathrm{G}^{*}$ & 545 & 13 & No \\
\hline 15 & $3471 \mathrm{G}>\mathrm{A}$ & 1157 & 1 & Yes \\
\hline 5 & $3499 \mathrm{G}>\mathrm{A}$ & 1167 & 1 & Yes \\
\hline 15 & $3606 \mathrm{~T}>\mathrm{C}$ & 1202 & 1 & Yes \\
\hline 15 & $4326 \mathrm{~T}>\mathrm{A}^{*}$ & 1442 & 1 & Yes \\
\hline 15 & $4479 \mathrm{G}>\mathrm{A}^{*}$ & 1493 & 9 & No \\
\hline 15 & $4497 \mathrm{G}>\mathrm{A}$ & 1499 & 2 & Yes \\
\hline 15 & $5034 \mathrm{~A}>\mathrm{G}^{*}$ & 1678 & 40 & No \\
\hline 15 & $5268 \mathrm{G}>\mathrm{T}^{*}$ & 1756 & 21 & No \\
\hline 15 & $5880 \mathrm{~A}>\mathrm{G}^{*}$ & 1960 & 45 & No \\
\hline 15 & $6948 \mathrm{~A}>\mathrm{G}$ & 2316 & 1 & Yes \\
\hline${ }^{*}$ Causative mutation identified in patients with this variant & 2307 & 1 & Yes \\
\hline
\end{tabular}

\section{Results}

In total, 70 patients out of the 112 harboured missense changes in the APC gene and out of these a significant proportion harboured multiple changes. There were 13 silent polymorphisms (mutations that do not change an amino acid or elicit aberrant splicing) identified throughout the APC gene. The majority of these were located in exon 15 of the APC gene and are listed in Table 2. A total of eight new silent polymorphisms were identified, one in exon 12 and seven in exon 15 (see Fig. 1 for their relative position in the APC gene). In exon 15 a total of 6 silent polymorphisms were identified and 5 normal variants (occurring more than twice in the population under study) none of which appeared to be associated with disease. A summary of the frequency of the silent changes is shown in Table 3, indicating their frequency and combination. Two of the normal variants (positions 5034 and 5880) were for the majority of patients in linkage disequilibrium with one another. A third

Table 3. Frequency of missense changes identified and their association with one another in the APC gene

\begin{tabular}{|c|c|c|c|c|c|c|c|}
\hline \multirow[b]{2}{*}{ Codon/Codon } & \multicolumn{7}{|c|}{ Number of times identified } \\
\hline & 545 & 1493 & 1499 & 1678 & 1756 & 1822 & 1960 \\
\hline 545 & $13^{*}$ & 3 & 1 & 12 & 11 & 3 & 12 \\
\hline 1493 & & 9 & 0 & 5 & 5 & 4 & 7 \\
\hline 1499 & & & 2 & 2 & 1 & 1 & 2 \\
\hline 1678 & & & & 40 & 17 & 18 & 35 \\
\hline 1756 & & & & & 21 & 6 & 17 \\
\hline 1822 & & & & & & 23 & 20 \\
\hline 1960 & & & & & & & 48 \\
\hline
\end{tabular}




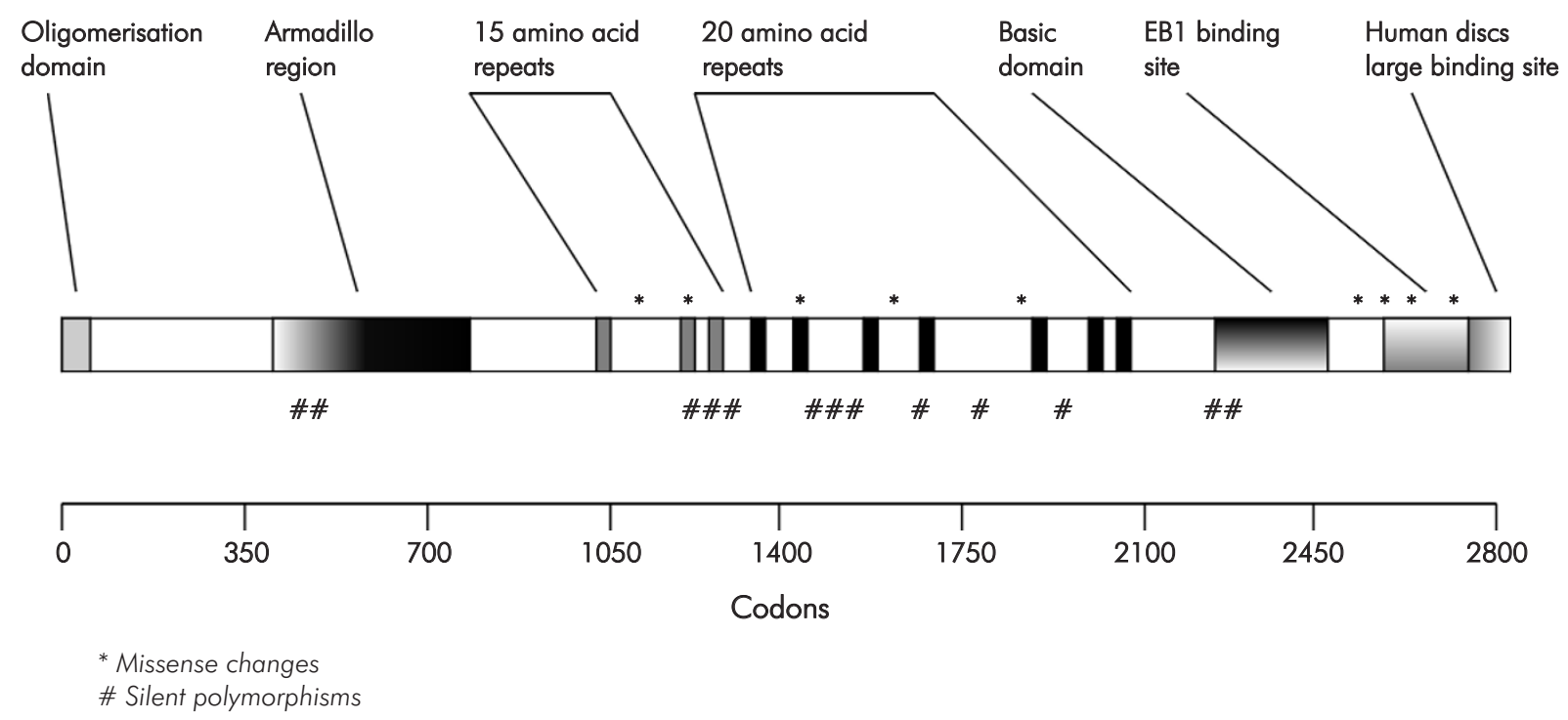

Fig. 1. Schematic diagram of the APC gene indicating the location of the missense changes identified in the APC gene. Missense mutations are indicated above the gene and silent polymorphisms are below the gene

common variant (position 1635) appeared to be in almost complete linkage disequilibrium with both changes. The fourth common variant at position 4479 was only rarely observed segregating with more than one other common variant. The common variant at position 5034 was observed 4 separate times in isolation in 4 unrelated patients. Ten patients were shown to harbour the 5880 common variant that was not in linkage disequilibrium with any other change. The correlation coefficients capturing the level of linkage disequilibrium between these polymorphisms are shown in Table 4. As can be seen, the polymorphisms at positions 5034, 5465 and 5880 are in strong linkage disequilibrium with each other and in turn with $4479(p<0.001)$. This degree of linkage disequilibrium leads to 1 common haplotype and a series of much rarer haplotypes, listed in Table 5. Almost $75 \%$ of all chromosomes have the wild type allele at all 4 positions $(5034,5465,5880$ and 4479).

From the 112 index cases studied a total of 42 patients harboured 9 missense changes dispersed across the coding region of the APC gene (see Fig. 1 and Table 6). Examination of the clinical features of families harbouring missense mutations in the APC gene did not reveal any specific characteristic that could be used for potential selection purposes (see Table 7 for details). One missense variation was considered to be a common variant and there were five missense

Table 4. Allelic correlation coefficients $(r)$ between two polymorphisms

\begin{tabular}{|c|c|c|c|c|c|}
\hline Polymorphisms & 4479 & 4497 & 5034 & 5880 & 5465 \\
\hline 4479 & 1 & & & & \\
\hline 4497 & $\begin{array}{c}-0.04 \\
(p=0.702)\end{array}$ & 1 & & & \\
\hline 5034 & $\begin{array}{c}0.13 \\
(p=0.106)\end{array}$ & $\begin{array}{c}0.16 \\
(p=0.040)\end{array}$ & 1 & & \\
\hline 5880 & $\begin{array}{c}0.21 \\
(p=0.006)\end{array}$ & $\begin{array}{c}0.13 \\
(p=0.063)\end{array}$ & $\begin{array}{c}0.51 \\
(p=<0.001)\end{array}$ & 1 & \\
\hline 5465 & $\begin{array}{c}0.16 \\
(p=0.083)\end{array}$ & $\begin{array}{c}0.08 \\
(p=0.405)\end{array}$ & $\begin{array}{c}0.35 \\
(p=<0.001)\end{array}$ & $\begin{array}{c}0.30 \\
(p=<0.001)\end{array}$ & 1 \\
\hline
\end{tabular}

$P$ - value of likelihood ratio test 
mutations that have not previously been described. From the 42 patients, 4 were found to harbour two missense changes of which two patients were homozygotes for one common variant (D1822V), one had two mutations (R1640W and A2696T) and one had 2 common variants (D1822V and S2621C). For a complete list of missense changes see Table 6 (for details of the site and affect of the changes). A total of 28 patients were found to be harbouring a common variant (D1822V), which was deemed not to be associated with any increased risk of colorectal cancer. This was further verified in a series of 67 unaffected healthy control subjects and found to be present at a frequency of $40 \%$, which was not statistically different from the group of FAP patients. Within this group, the same frequency of homozygote individuals was observed as found in the patient population.

Two of the patients were found to harbour a previously reported causative missense change (S2621C), which results in a change from a serine to a cysteine. This

Table 5. Haplotype frequencies

\begin{tabular}{lcc}
\hline Locus & Number & Percentage \\
\hline 1.1 .1 .1 & 164 & $73.21^{*}$ \\
\hline 1.1 .1 .2 & 1 & 0.45 \\
\hline 1.1 .2 .1 & 5 & 2.23 \\
\hline 1.1 .2 .2 & 0 & 0 \\
\hline 1.2 .1 .1 & 9 & 4.02 \\
\hline 1.2 .1 .2 & 1 & 0.45 \\
\hline 1.2 .2 .1 & 3 & 1.34 \\
\hline 1.2 .2 .2 & 1 & 0.45 \\
\hline 2.1 .1 .1 & 3 & 1.34 \\
\hline 2.1 .1 .2 & 0 & 0 \\
\hline 2.1 .2 .1 & 2 & 0.89 \\
\hline 2.1 .2 .2 & 0 & 0 \\
\hline 2.2 .1 .1 & 18 & $8.04^{*}$ \\
\hline 2.2 .1 .2 & 2 & 0.89 \\
\hline 2.2 .2 .1 & 12 & $5.36^{*}$ \\
\hline 2.2 .2 .2 & 3 & 1.34 \\
\hline Total & 224 & 00.00 \\
\hline & 0.04501 & 0.4449 \\
\hline
\end{tabular}

Locus position 1, 2, 3, 4 correspond to 5034, 5880, 5465, and 4479 respectively. Each locus has two alleles: $1=$ wild type and $2=$ mutant type change could not be shown to exclusively segregate with disease status.

Of the remaining missense mutations, 5 were identified in more than one unrelated patient and four appeared to be unique. Two mutations were identified in the mutation cluster region (E1317Q and M1413V) and the remaining two were located towards the extreme $3^{\prime}$ end of the APC gene (G2502S and A2696T). One missense mutation (L1129S) was identified immediately upstream of the $\beta$-catenin binding region of the APC gene in two unrelated patients.

Only three changes were identified within the $\beta$-catenin down regulatory region of the APC gene. One of the changes (M1413V) found in the $\beta$-catenin down regulatory region was homozygous in one patient who also harboured the common D1822V polymorphism. In further testing of other family members this combination was also identified in unaffected relatives. The second patient found to have the M1413V change was subsequently shown to harbour a mutation, which resulted in a premature termination codon.

Segregation analysis of the D1822V and the S2621C changes in one family revealed no apparent association with disease when both alleles were inherited together. One individual was heterozygote for D1822V and S2621 C and affected with disease; three healthy siblings were homozygote for the D1822V change, of which two also were heterozygote for the S2621C mutation.

There were a series of patients from this study group that harboured more than one silent and/or missense change. There were 13 patients who harboured 4 or more polymorphisms, from which 2 unrelated patients were shown to harbour seven common alterations in the APC gene (see Table 3 for summary). 11 (9.8\%) of the patients included in this study were subsequently shown to harbour germline causative changes in the APC gene that resulted in either premature termination codons $(10 / 11)$ or a complete gene deletion (1/11). All of these patients harboured one or more missense mutations.

Examination of the clinical features of families harbouring missense mutations in the APC gene indicated some suggestive associations, although none reached statistical significance (see Tables 7 and 8 for details). As mentioned previously, the most common polymorphisms, at positions 5034, 5880 and 5465, were in reasonably high linkage disequilibrium and so these were considered as a group. Having a polymorphic allele at one or more of these 3 sites increased the risk of having moderate/severe disease by 1.6 fold ( $95 \% \mathrm{Cl} 0.7-3.6)$, as shown in Table 8a. Furthermore, the polymorphism at position 4479 appeared to have a protective effect, 
Table 6. Missense changes identified in exon 15 of the APC gene

\begin{tabular}{|c|c|c|c|c|c|}
\hline Exon & Nucleotide & Codon & $\begin{array}{l}\text { Reported in } \\
\text { Human Genome Database }\end{array}$ & $\begin{array}{l}\text { Number of } \\
\text { observations }\end{array}$ & New \\
\hline 15.5 & $3386 \mathrm{~T}>\mathrm{C}$ & L11129S & No & 2 & Yes \\
\hline 15.7 & $3949 \mathrm{G}>C$ & E1317Q & Yes & 2 & No \\
\hline 15.8 & $4237 \mathrm{~A}>\mathrm{G}^{*}$ & M1413V & No & 1 & Yes \\
\hline 15.10 & $4918 \mathrm{C}>\mathrm{T}$ & R1640W & Yes & 1 & No \\
\hline 15.12 & $5465 \mathrm{~A}>\mathrm{T}^{*}$ & D1822V & Yes & 23 & No \\
\hline 15.19 & $7406 \mathrm{C}>\mathrm{T}^{*}$ & S2469F & No & 2 & Yes \\
\hline 15.19 & $7504 \mathrm{G}>\mathrm{A}^{*}$ & G2502S & No & 3 & Yes \\
\hline 15.20 & $7862 C>G$ & S2621C & Yes & 2 & No \\
\hline 15.21 & $8068 \mathrm{G}>\mathrm{A}$ & A2696T & No & 1 & Yes \\
\hline
\end{tabular}

decreasing the risk of moderate/severe disease to 0.4 (95\% $\mathrm{Cl} 0.1-2.8)$ as shown in Table 8b.

All the missense changes were studied using an algorithm that identifies the presence of exon splice enhancer (ESE) regions within the coding sequence genes (http://genes.mit.edu/cgi-bin/rescue-ese/). The results of this investigation revealed that the majority of changes did not result in any putative ESE binding site changes. There were, however, nine polymorphisms (both silent changes and missense mutations) that the prediction algorithm identified as having an effect (see Table 9). Of the nine changes 6 were predicted to result in the addition of one or more ESE binding motifs and 2 - the loss of one or more motifs.

\section{Discussion}

There has been a paucity in reporting missense changes in the APC gene by virtue of the fact that the majority of investigators use the PTT to screen for mutations in the APC gene. The PTT is an excellent screen for mutations that either result in immediate termination codons or for insertion or deletion mutations that eventuate in frameshiffs culminating in downstream stop codons but it cannot identify amino acid substitutions. Little information is available in the published literature about missense changes, silent or not, that have the capacity to affect the functioning of the expressed protein. In this report we have specifically targeted the identification of missense changes in the APC gene to determine if any of them could be unequivocally associated with an increased risk of colorectal cancer.
Detailed examination of exon 15 of the APC gene revealed in the study population 6 silent polymorphisms that occurred with a frequency varying from $1.8 \%$ to $42 \%$. Some of the polymorphisms were in linkage disequilibrium with one another, and these have previously been reported [25]. One haplotype accounts for almost $75 \%$ of all chromosomes; however, linkage disequilibrium is not complete and is suggestive of recombination between these polymorphisms.

Irrespective of linkage disequilibrium being incomplete it was sufficient to allow for an analysis of the contribution one or more missense changes can have to disease. In the results presented herein we were able to identify an association (although not statistically significant in this small sample population) between three missense changes (at positions 5034, 5465 and/or 5880), which increases the risk of developing moderate to severe disease and an apparent protective affect of missense change at position 4479.

These results present a challenge to our concept of disease risk as they cannot be readily explained by examining the functional affects on the APC protein. Recently, a new notion has been put forward to explain the paucity of causative missense mutations in the APC gene, known as the "Just-Right" signalling hypothesis. This theory suggests that APC driven tumourigenesis is related to the amount of residual $\beta$-catenin down regulatory activity centred around the $7 \beta$-catenin binding and down regulatory regions in the APC protein. The loss of these sites appears to be related to disease phenotype, since if all are lost there is too much accumulation of $\beta$-catenin, which at a cellular level is fatal as it triggers 
Table 7. Disease characteristics in the families identified with missense mutations in the APC gene

\begin{tabular}{|c|c|c|c|c|c|c|}
\hline Family mutation & $\begin{array}{l}\text { Age of } \\
\text { onset }\end{array}$ & $\begin{array}{c}\text { Age of } \\
\text { death }\end{array}$ & Sex & $\begin{array}{l}\text { Family } \\
\text { history }\end{array}$ & $\begin{array}{l}\text { Disease } \\
\text { phenotype }\end{array}$ & $\begin{array}{l}\text { Extra-colonic } \\
\text { disease }\end{array}$ \\
\hline codon 1822 & 26 & - & Male & Yes & Polyposis & No \\
\hline (hom) & 48 & 48 & Male & & Polyposis & No \\
\hline \multirow[t]{4}{*}{ codon 1822} & 36 & - & Female & Yes & Polyposis & No \\
\hline & 43 & - & Male & & Bowel Cancer & No \\
\hline & 40 & - & Male & & Polyposis & No \\
\hline & 43 & 46 & Male & & Bowel & No \\
\hline \multirow[t]{2}{*}{ codon $2502^{*}$} & 39 & 53 & Female & Yes & Polyposis & Leiomyoma \\
\hline & 49 & - & Male & & Polyposis & Upper GI Polyposis \\
\hline \multirow[t]{2}{*}{ codon 1317} & 48 & - & Male & Yes & Polyposis & No \\
\hline & 35 & - & Male & & Polyposis & No \\
\hline \multirow[t]{4}{*}{ codon 2502} & 45 & - & Male & Yes & Polyposis & No \\
\hline & - & 77 & Male & - & & Renal Cancer \\
\hline & - & 60 & Female & - & & Multiple Myeloma \\
\hline & - & 66 & Female & - & & Breast Cancer \\
\hline codon 1129 & 12 & 29 & Male & No & Polyposis & No \\
\hline codon 1640 & 38 & 47 & Male & Yes & Polyposis & CHRPE \\
\hline \multirow[t]{3}{*}{ and 2696} & - & 42 & Male & - & & Melanoma \\
\hline & - & 57 & Male & & Polyposis & \\
\hline & - & - & Male & & Unknown & Unknown \\
\hline codon 1822 & 31 & - & Female & Yes & Polyposis & No \\
\hline \multirow[t]{2}{*}{ (hom) } & 42 & - & Male & & Polyposis & No \\
\hline & 26 & 27 & Male & & Bowel Cancer & No \\
\hline \multirow[t]{5}{*}{ codon 2502} & 38 & - & Female & & $\begin{array}{l}\text { Rectal Cancer } \\
\text { Multiple adenomas }\end{array}$ & No \\
\hline & 44 & - & Male & & $\begin{array}{l}\text { Bowel Cancer } \\
\text { Multiple adenomas }\end{array}$ & \\
\hline & - & $80 \mathrm{~s}$ & Male & & Bowel Cancer & No \\
\hline & 28 & - & Female & & Multiple adenomas & No \\
\hline & 34 & - & Male & & Multiple adenomas & \\
\hline codon 1129 & 62 & - & Male & No & Polyposis & $\begin{array}{l}\text { Bowel } \\
\text { Cancer } \\
\text { Upper GI } \\
\text { Polyposis }\end{array}$ \\
\hline codon 1413* & 35 & - & Female & No & Bowel Cancer & No \\
\hline
\end{tabular}


programmed cell death [26]. Partial retention of one or more of the binding sites is likely to result in a severe disease phenotype and promote the development of colorectal cancer since there is sufficient control over $\beta$-catenin [27]. Since there are $7 \beta$-catenin binding and down regulatory regions in the APC gene the affect of one or two missense changes in the APC gene would not be sufficient to radically alter this important role of the APC protein. Indeed, we were able to perform segregation analysis on one large family that harboured three separate missense mutations, which showed that the missense changes clearly did not segregate with disease. This coupled with the notion that missense changes will not be sufficient to alter the primary function of the APC protein offers an explanation as to why missense mutations occur so frequently in the APC gene and second, why they do not result in disease.

An alternative notion should also be considered since it offers a novel and plausible explanation as to why some missense changes have been described as pathogenic. Most of the missense changes described herein conform to the notion that missense changes do not alter the function of the APC protein. There has been little focus on the role of missense changes and how they may relate to mRNA processing. Mutations occurring at canonical splice sites are known to result in splicing changes that can be pathogenic but more recent evidence is beginning to shed light on the role of exon splice enhancer and exon splice suppressor motifs and their role in gene expression.

Any alteration in the control of exon splicing could potentially result in a RNA species that either contains more or less genetic information. Importantly, if the change results in a differentially spliced mRNA species, the resultant splice variant will not necessarily be recognised as an error and therefore not be removed by the process of nonsense mediated mRNA decay since there will be no premature stop codon to initiate this process.

Examination of the changes elicited at the genetic level suggest an alternative hypothesis explaining why some missense changes are pathogenic and others are not. For example, there have been extensive studies examining the pathogenicity of the Ashkenazi I1307K change, which has been implicated in disease risk. The current explanation focuses on the position of this missense mutation and its proximity to the most frequently described mutation at codon 1309, which is associated with a severe disease phenotype [20]. Codon 1309 is located within the $\beta$-catenin binding domain of APC (see Fig. 1). The 11307K change occurs within the $\beta$-catenin binding domain and is believed to disrupt the kinetics of $\beta$-catenin binding to APC. If the "Just-Right" signalling hypothesis is correct then it
Table 8a, b. Disease severity and its association with the four common polymorphic alleles identified as being in linkage disequilibrium

a. Association between polymorphisms at $5034,5465,5880$

and disease severity

\begin{tabular}{lcc}
\hline & Moderate/severe & Mild \\
\hline At least 1 polymorphic allele & 41 & 20 \\
\hline Wild type at all 3 sites & 33 & 26 \\
\hline
\end{tabular}

$\mathrm{OR}=1.62(0.70-3.63)$

b. Association between polymorphism 4479 and disease severity

\begin{tabular}{lcc}
\hline & Moderate/severe & Mild \\
\hline Polymorphic allele & 3 & 4 \\
\hline Wild type & 71 & 42
\end{tabular}

$\mathrm{OR}=0.44(95 \% \mathrm{Cl} 0.06-2.78)$

is difficult to reconcile this conundrum. Similarly, a second missense variant that has been associated with FAP, the E1317Q change, is even more problematic and the only suggestion to date has been the creation of a hypermutable site $[20,28]$. If the genetic changes are assessed for their effect on the presence of ESE motifs the results suggest that these are especially important. Both of these changes result in a change in ESE motif structure and are likely to have more influence on differential mRNA splicing, which is could result in the creation of mRNA species that would result in proteins incapable of being fully functionally active. The expected result of these changes would be a mild phenotype consistent with the notion that haploinsufficiency is sufficient to initiate disease development. The remaining question which has not been addressed here would be: what reduction in full length APC mRNA is required to change the likelihood of disease development?

In relation to the observed association between the three missense changes (at codons 1678, 1960 and D1822V) and disease severity this model does offer an explanation as to the apparent pathogenicity of these changes and the "Just-Right" signalling model. Furthermore, the protective effect of the codon 1493 change can also be accommodated by this notion.

In summary, none of the 13 polymorphisms or 9 missense changes could be unequivocally associated with changing the functional role of the APC protein and thereby the risk of developing polyposis. From the 22 changes identified 9 of them were associated with a change in exon splice enhancer motifs that are more likely to change disease risk via the production of differential forms of the APC gene that could be 
Table 9. Effect of missense mutations on ESE binding motifs

\begin{tabular}{lll}
\hline $\begin{array}{l}\text { Nucleotide } \\
\text { position }\end{array}$ & $\begin{array}{l}\text { Change in } \\
\text { ESE motifs }\end{array}$ & $\begin{array}{c}\text { Potential } \\
\text { effect }\end{array}$ \\
\hline Silent Polymorphisms & &
\end{tabular}

Silent Polymorphisms

\begin{tabular}{lll}
\hline $1554 G>A$ & No & None \\
\hline $1635 \mathrm{~A}>\mathrm{G}$ & No & None \\
\hline $3471 \mathrm{G}>\mathrm{A}$ & Yes & Add \\
\hline $3499 \mathrm{G}>\mathrm{A}$ & No & None \\
\hline $3606 \mathrm{~T}>\mathrm{C}$ & No & None \\
\hline $4326 \mathrm{~T}>\mathrm{A}$ & No & None \\
\hline $4479 \mathrm{G}>\mathrm{A}$ & Yes & Add \\
\hline $4497 \mathrm{G}>\mathrm{A}$ & Yes & Add \\
\hline $5034 \mathrm{~A}>\mathrm{G}$ & Yes & Add \\
\hline $5268 \mathrm{G}>\mathrm{T}$ & No & None \\
\hline $5880 \mathrm{~A}>\mathrm{G}$ & No & None \\
\hline $6948 \mathrm{~A}>\mathrm{G}$ & Yes & Loss \\
\hline $6921 \mathrm{G}>\mathrm{A}$ & Yes & Add \\
\hline
\end{tabular}

\begin{tabular}{lll}
\hline Missense Mutations & & \\
\hline $3386 \mathrm{~T}>\mathrm{C}$ & No & None \\
\hline $3949 \mathrm{G}>\mathrm{C}$ & No & None \\
\hline $4237 \mathrm{~A}>\mathrm{G}$ & Yes & Loss \\
\hline $4918 \mathrm{C}>\mathrm{T}$ & No & None \\
\hline $5465 \mathrm{~A}>\mathrm{T}$ & Yes & Add \\
\hline $7406 \mathrm{C}>\mathrm{T}$ & No & None \\
\hline $7504 \mathrm{G}>\mathrm{A}$ & No & None \\
\hline $7862 \mathrm{C}>\mathrm{G}$ & No & None \\
\hline $8068 \mathrm{G}>\mathrm{A}$ & Yes & Complex\# \\
\hline$+3921 \mathrm{P}>\mathrm{A}(11307 \mathrm{~K})$ & Yes & Complex* \\
$+3951 \mathrm{C}>\mathrm{G}$ (E1317Q) & Yes & Add \\
\hline
\end{tabular}

Add $=$ adds a new ESE motif; Loss = removes an ESE motif

\#This change results in the removal of 5 ESE motifs and the creation of an additional ESE motif

*This change combines one independent ESE motif with an adjacent one

+These polymorphisms were not identified in the current study

capable of reducing the affective levels of APC protein and thereby change disease risk.

\section{Acknowledgements}

The authors wish to thank the patients and clinicians who provided information for this study and Prof. R.
Fodde for critically evaluating the manuscript prior to submission. The study was funded in part by the Hunter Medical Research Institute and small grants from the Australian Research Council. The authors acknowledge the contribution of the Clive and Vera Ramaciotti Functional Genomics centre without which none of this work would have been possible.

\section{References}

1. Bufill JA. Colorectal cancer genetics. Closing the gap between genotype and phenotype. Cancer 1995 (Phila.); 76: 2389-2392.

2. Lynch HT, Smyrk TC, Watson P, Lanspa SJ, Lynch PM, Jenkins JX, Rouse J, Cavalieri J, Howard L and Lynch J. Hereditary flat adenoma syndrome: a variant of familial adenomatous polyposis? Dis Colon Rectum 1992; 35: 411 -421.

3. Spirio L, Olschwang S, Groden J, Robertson M, Samowitz W, Joslyn G, Gelbert L, Thliveris A, Carlson M, Otterud B et al. Alleles of the APC gene: an attenuated form of familial polyposis. Cell 1993, 75: 951-957.

4. Herrera L, Kakati S, Gibas L, Pietrzak E and Sandberg AA. Gardner syndrome in a man with an interstitial deletion of $5 q$. Am J Med Genet 1986; 25: 473-476.

5. Bodmer WF, Bailey CJ, Bodmer J, Bussey HJ, Ellis A, Gorman P, Lucibello FC, Murday VA, Rider SH, Scambler P, Sheer D, Solomon $E$ and Spurr NK. Localization of the gene for familial adenomatous polyposis on chromosome 5. Nature 1987; 328: 614-616.

6. Joslyn G, Carlson M, Thliveris A, Albertsen H, Gelbert L, Samowitz W, Groden J, Stevens J, Spirio L, Robertson M, et al. Identification of deletion mutations and three new genes at the familial polyposis locus. Cell 1991; 66: 601-613.

7. Groden J, Thliveris A, Samowitz W, Carlson M, Gelbert L, Albertsen H, Joslyn G, Stevens J, Spirio L, Robertson M, et al. Identification and characterization of the familial adenomatous polyposis coli gene. Cell 1991, 66: 589-600.

8. Nishisho I, Nakamura Y, Miyoshi Y, Miki Y, Ando H, Horii A, Koyama K, Utsunomiya J, Baba S and Hedge P. Mutations of chromosome $5 q 21$ genes in FAP and colorectal cancer patients. Science 1991; 253: 665-669.

9. Kinzler KW, Nilbert MC, Su L-K, Vogelstein B, Bryan TM, Levy DB, Smith KJ, Preisinger AC, Hedge P, McKechnie D, et al. Identification of FAP locus genes from chromosome 5q21. Science 1991; 253: 661-665.

10. Rubinfeld B, Albert I, Porfiri E, Fiol C, Munemitsu S and Polakis P. Binding of GSK3 $\beta$ to the APC- $\beta$-Catenin complex and regulation of complex assembly. Science 1996; 272: 1023 1026.

11. Su L-K, Burrell M, Hill DE, Gyuris J, Brent R, Wiltshire R, Trent J, Vogelstein B and Kinzler KW. APC binds to the novel protein EB1. Cancer Res 1995; 55: 2972-2971.

12. Matsumine A, Ogai A, Senda T, Okumura N, Satoh K, Baeg GH, Kawahara T, Kobayashi S, Okada M, Toyoshima K and Akiyama T. Binding of APC to the human homolog of the Drosophila discs large tumor suppressor protein. Science 1996; 272: 1020-1023.

13. Myoshi Y, Nagase H, Ando H, Horii A, Ichii S, Nakatsuru S, Aoki T, Miki Y, Mori T and Nakamura Y. Somatic mutations of the APC gene in colorectal tumors: mutation cluster region in the APC gene. Hum Mol Genet 1992; 1: 229-233.

14. Van der Luijt R, Khan PM, Vasen H, van Leeuwen C, Tops C, Roest P, den Dunnen J and Fodde R. Rapid detection of translation-terminating mutations at the adenomatous polyposis 
coli (APC) gene by direct protein truncation test. Genomics 1994; 20: 1-4.

15. Fearnhead NS, Britton MP and Bodmer WF. The ABC of APC. Hum Mol Genet 2001; 10: 721 -733.

16. Ruiz-Ponte C, Vega A, Carracedo A and Barros F. Mutation analysis of the adenomatous polyposis coli (APC) gene in northwest Spanish patients with familial adenomatous polyposis (FAP) and sporadic colorectal cancer. Hum Mut 2001; Online.

17. Heinimann $K$, Thompson A, Locher A, Furlanetto T, Bader E, Wolf A, Meier R, Walter K, Baverfeind P, Marra G, Muller H, Foernzler $D$ and Dobbie Z. Nontruncating APC germ-line mutations and mismatch repair deficiency play a minor role in APC mutation-negative polyposis. Cancer Res 2001; 61: 7616-7622.

18. Breast Cancer Information Core: http://research.nhgri.nih.gov/ projects/bic

19. ICG-HNPCC: http://www.nfdht.nl/database/mdbchoice.htm

20. Frayling IM, Beck NE, llyas M, Dove-Edwin I, Goodman P, Pack K, Bell JA, Williams CB, Hodgson SV, Thomas HJ, Talbot IC, Bodmer WF and Tomlinson IP. The APC variants I1307K and E1317Q are associated with colorectal tumors, but not always with a family history. Proc Natl Acad Sci USA 1998; 95: 10722-10727.

21. Miller SA, Dykes DD and Polesky H. A simple salting out procedure for extracting DNA from human nucleated cells. Nucleic Acids Res 1988; 53: 739

22. Scott RJ, Meldrum C, Crooks R, Spigelman AD, Kirk J, Tucker K and Koorey D, the Hunter Family Cancer Service. Familial adenomatous polyposis: more evidence for disease diversity and genetic heterogeneity. Gut 2001; 48: 508-514.

23. Mander AP. Haplotype analysis in population-based association studies. Stata Journal 2002; 1: 58-75.

24. StataCorp. Stata statistical software: Release 8.0. In TX: Stata Corporation, College Station 2003.

25. Gayther SA, Sud R, Wells D, Tsioupra K and Delhanty JDA. Rapid detection of rare variants and common polymorphisms in the APC gene by PCR-SSCP for presymptomatic diagnosis and showing allele loss. J Med Genet 1995; 32: 568-571.

26. Kim K, Pang KM, Evans M and Hay ED. Overexpression of beta-catenin induces apoptosis independent of its transactivation function with LEF-1 or the involvement of major $\mathrm{Gl}$ cell cycle regulators. Mol Biol Cell 2000; 1 1: 3509-23.

27. Albuquerque $C$, Breukel $C$, van der Luij $R$, Fidalgo $P$, Lage $P$, Slors FJ, Leitao CN, Fodde R and Smits R. The "just-right" signaling model: APC somatic mutations are selected based on a specific level of activation of the $\beta$-catenin signaling cascade. Hum Mol Genet 2002; 11: 1549-1560.

28. Lamlum H, Al Tassan N, Jaeger E, Frayling I, Sieber O, Reza FB, Eckert M, Rowan A, Barclay E, Atkin W, Williams C, Gilbert J, Cheadle J, Bell J, Houlston R, Bodmer W, Sampson J and Tomlinson I. Germline APC variants in patients with multiple colorectal adenomas, with evidence for the particular importance of E1317Q. Hum Mol Genet 2000; 9: 2215-2221. 